\title{
Study Habits of Underachievers at Palembang State High School 3
}

\author{
Lia Rizqi Pratiwi* \\ Graduate Program \\ Universitas Negeri Yogyakarta \\ Yogyakarta, Indonesia \\ liarizqi.2018@student.uny.ac.id*
}

\author{
Muh Farozin \\ Guidance and Counseling Department \\ Universitas Negeri Yogyakarta \\ Yogyakarta, Indonesia \\ farozin2311@yahoo.com
}

\begin{abstract}
The purpose of this study is to figure out the study habits of underachieving students at Palembang State High School 3. A quantitative approach with a survey method was employed in this study. The population included 30 underachieving students. The data collection instrument was a Likert-scale questionnaire which included three aspects of the implementation and planning of study schedules, concentration, and working on assignments. The results show that $70 \%$ of underachieving students at Palembang State High School 3 have good study habits.
\end{abstract}

Keywords - study habit, underachiever student

\section{INTRODUCTION}

National Education System Law No. 20 of 2003 Chapter 2 Article 3 explains that education functions to develop capabilities and build the character and civilization of a dignified nation in the context of intellectual life of the nation. It aims to develop the potential of students to become human beings who believe and fear God Almighty, have noble characters, are healthy, knowledgeable, capable, creative, independent, and become democratic and responsible citizens [1].

Education facilitates students to achieve. The learning process in education is one of the efforts to realize educational goals to facilitate students in achieving optimal development, which is a situation where students can actualize the potential within themselves. One indicator of the achievement of the student's learning success can be seen from their achievements.

The results of education are said to be quality if the education that is carried out can provide skills, knowledge, and skills to the graduates are useful to pursue higher education or to enter the workforce. Updates and development of the field of education are indispensable to create a quality education that suits the needs of society. This will be achieved when the learning process is executed effectively so that the educational results can be optimal.

One indicator of successful student learning achievement can be seen from the achievement. The importance of knowing the students ' learning achievement in school is to know how far students can master and understand the materials of the subjects that teachers have taught in school. Good learning achievement is the expectation of all parties both from students themselves, teachers, parents, and school.
However, not all students can obtain learning achievements in accordance with their potentials. Student learning achievements are influenced by internal factors and external factors. Internal factors include: a) physiological factors such as health, physical condition, five senses, b) psychological factors such as intelligence, creativity, talent, interests, attitudes, motivation, memory, learning habits, and intelligence. While the extenern factors include the way parents educate, teachers, curriculum, classroom participation, teaching teacher methods, learning tools, learning media, and the form of community life.

Intelligence is one factor predicted as the main cause of the student's learning achievement. Therefore, the level of intelligence is often used to determine the ability to learn and the achievements that students seek [2].

Generally, a person with good intelligence (high IQ) can learn easily and the results tend to be good, different from a person with low intelligence, who tends to experience difficulties in learning, has slow thinking, and low achievement. Students who have an intelligence level above 120 in the intelligence test are predicted to have no difficulty in learning and getting learning achievement in school. In reality, many students with a high level of intelligence still have difficulty in completing school assignments and have achievements below their potentials. This type of students in the context of Psychology and Guidance and Counseling is known as an underachiever [3].

The underachiever cases are found from elementary, junior high school and even higher education. High School as a formal education organizing agency aims to create or prepare learners to have the ability to continue to a higher level of education. One of the businesses used to realize that goal is to improve student learning performance. The learning achievement is a major benchmark to know the success of one's learning, one of which is the learning achievement of high school students.

Many high-school students have high intelligence but are unable to show good performance [4]. Students are classified as underachievers based on the results of the intelligence and creativity tests. The results of this study explain that some students do not show learning achievements in accordance with their potentials in the school [5]. Underachieving students are first determined by the characteristics of their potentials and achievements. The potentials of the students generally determined by the intelligence test are expressed scores while the achievements 
are expressed in grades [6]. Underachieving students tend to have no interest in learning and study habits of liking to postpone doing assignments at home and at school. These attitudes make students' learning achievements not good [7].

According to research, underachiever children in America have found about $10 \%-40 \%$ of the child's population gifted. Why the child gifted?. Because the study of the underachiever child is usually done to the child gifted, whose IQ is above average. Underachievers are experienced by many intellectually gifted students who have an IQ level above 120.

In Indonesia, students at Senior High School 1 Bangkinang has good learning achievement, but there are still differences in the achievement of students in the report. Some students include to underachiever category because their intelligence results are not in accordance with the average achievement, such as there are still students who get an average achievement of 75.00. The number of students who have to follow remedial for some subjects because of the achievement they gained from the exam results does not reach the minimum submission criteria already set by the school in each subject.

Other facts are also found in the students at Senior High School 2 Bandung that from 78 students who belong to a high capacity of 32 people or about 41 percent of the students are underachieving. These students include the underachiever category [8]

Students who have a high level of intelligence can get good learning outcomes if they have good study habits and the environment that has a positive influence. The study habit behaviors of liking to postpone doing assignments, indiscipline in learning and self-regulation can determine the learning achievements of underachievers. On the other hand, the students with a high level of intelligence that are not supported by good study habits might get poor learning outcomes. Good study habits will determine the learning achievements of the students [9].

Home environment can cause students to be underachiever, which is how nearby people treating the child will influence the achievement of students in achieving. Families are the most important factor that can cause students to experience underachievers, such as a lack of parental positive attitude toward student achievement, parents are too dominant in student learning, lack of attention, support and parental readiness to help his son in his home study.

The school is also a contributing factor in the cause of underachievers in students, such as how teaching, materials, and measures of success and ability of the teacher can lead to underachiever children. Teachers play an important role in student achievement, the how teachers in treating their students will influence the achievement that the student will achieve. Schools can support and help to facilitate and provide intervention to underachieving students. One party that has a role is the teacher of guidance and counseling [10]. Guidance and counseling is a process of assistance provided by guidance and counseling teachers to overcome and prevent problems faced by students. This can help them achieve optimal and good developmental and adjustment tasks.

One of the issues that needs to be addressed immediately by the teacher of guidance and counseling is of learning. Services in learning can be provided by the guidance and counseling teacher continuously during the learning activities. Guidance and counseling teachers are obliged to monitor the results of students' learning activities by working together with the class teacher. Guidance and counseling teachers are very instrumental in helping students to adjust themselves to the learning situation effectively and efficiently according to their abilities to achieve optimal development [11].

The intelligence test results in the field are generally found in senior high schools. Based on the observations by the researcher in Palembang, Public Senior High School 3 Palembang is one of the schools that conducts the student intelligence test. This is also supported by good and superior school standards and quality in Palembang. The results of observations show that there are several underachieving students in the eleventh grade based on the results of the intelligence test, learning achievements, and recommendations from the school. Therefore, the provision of guidance and counseling services can contribute to maximize the potentials of underachieving students [12].

Based on the observations and results of previous studies above, the researcher wanted to find out the study habits of underachieving students at the Palembang State High School 3. This is useful to provide understanding and help students actualize their potentials. In addition, the data generated can the guideline for the guidance and counseling service plans at the school.

\section{METHOD}

This study uses a quantitative-descriptive approach with a survey method. The population of this study are 30 eleventh-grade underachieving students. The instrument used to collect data is the Likert-Scale model. The data were collected using the study-habit questionnaire with three aspects of planning and implementing learning schedules, concentration, and doing assignments.

\section{RESULT AND DISCUSSION}

Result

The results of the study and data analysis show that the eleventh-grade underachieving students at Palembang State High School 3 have different study habits. Most eleventhgrade underachievers in Public Senior High School 3 Palembang have good study habits of $70 \%$ as shown in the following table:

Table 1. Percentage of Respondents in Underachiving

\begin{tabular}{|c|c|c|c|}
\hline \multicolumn{4}{|c|}{ Students' Study Habits } \\
\hline No. & Category & Frequency & $\%$ \\
\hline 1 & Very Good & 4 & 13 \\
\hline 2 & Good & 21 & 70 \\
\hline 3 & Quite Good & 5 & 17 \\
\hline 4 & Poor & - & - \\
\hline & Total & 30 & 100 \\
\hline
\end{tabular}

Based on the results of the data analysis, it can also be known more deeply about the aspects of underachieving students' study habits as shown in the following table: 
Table 2. Percentage of Respondents Based on Aspects of Underachiving Students' Study Habits

\begin{tabular}{|c|c|c|c|c|c|c|c|c|}
\hline \multirow{2}{*}{ Aspects } & \multicolumn{7}{|c|}{ Categories } \\
\cline { 2 - 11 } & \multicolumn{2}{|c|}{ VG } & \multicolumn{2}{|c|}{ G } & \multicolumn{2}{c|}{ QG } & \multicolumn{2}{c|}{ P } \\
\cline { 2 - 10 } & f & $\%$ & f & $\%$ & f & $\%$ & f & $\%$ \\
\hline $\begin{array}{c}\text { Planning \& } \\
\text { Implementing } \\
\text { Learning Schedules }\end{array}$ & 5 & 17 & 21 & 70 & 4 & 13 & - & - \\
\hline Concentration & - & - & 7 & 23 & 21 & 70 & 2 & 7 \\
\hline Doing Assignments & 1 & 3 & 18 & 60 & 11 & 37 & - & - \\
\hline
\end{tabular}

Table 3. Percentage of Respondents Based on The Planning and Implementation Aspect of Learning Schedule in Underachiving Students' Study Habits

\begin{tabular}{|c|c|c|c|}
\hline No. & Category & Frequency & $\begin{array}{c}\text { Percentage } \\
(\%)\end{array}$ \\
\hline 1. & Very Good & 5 & 17 \\
\hline 2. & Good & 21 & 70 \\
\hline 3. & Quite Good & 4 & 13 \\
\hline \multicolumn{2}{|r|}{ Total } & 30 & 100 \\
\hline
\end{tabular}

Based on the table above, the aspect of planning and implementing learning schedules of underachieving students is classified as good of $70 \%$.

Table 4. Percentage of Respondents Based on The Concentration Aspect in Underachiving Students' Study Habits

\begin{tabular}{|c|c|c|c|}
\hline No. & Category & Frequency & Percentage $(\%)$ \\
\hline 1. & Good & 7 & 23 \\
\hline 2. & Quite Good & 21 & 70 \\
\hline 3. & Poor & 2 & 7 \\
\hline \multicolumn{2}{|r|}{ Total } & 30 & 100 \\
\hline
\end{tabular}

Based on the table above, the aspect of concentration of underachieving students is classified as quite good of $70 \%$.

Table 5. Percentage of Respondents Based on The Doing The Assignment Aspect in Underachiving Students' Study Habits

\begin{tabular}{|c|c|c|c|}
\hline No. & Category & Frequency & Percentage (\%) \\
\hline 1. & Very Good & 1 & 3 \\
\hline 2. & Good & 18 & 60 \\
\hline 3. & Quite Good & 11 & 37 \\
\hline \multicolumn{2}{|c|}{ Total } & 30 & 100 \\
\hline
\end{tabular}

Based on the table above, the aspect of doing assignments of underachieving students is classified as good of $60 \%$. From the above description, we can conclude that there are 3 aspects in the study habits of underachieving students in Public Senior High School 3 Palembang with the following percentage: (1) the planning and implementation of learning schedules with a very good category of $17 \%$, good category of $70 \%$, and quite good category of $13 \%$, (2) the concentration with a good category of $23 \%$, a quite good category of $70 \%$, and poor category of $7 \%$, (3) the doing assignments with a very good category of $3 \%$, a good category of $60 \%$, and a quite good category of $37 \%$.

\section{Discussion}

From the study results and data analysis on the underachieving students' study habits, we found several categories of different levels. 4 students or $13 \%$ have very good study habits, 21 students or $70 \%$ have good study habits, and only 5 students or $17 \%$ have quite good study habits.
However, from the total respondents, no students have poor study habits. This shows that the eleventh-grade underachieving students at Public Senior High School 3 Palembang have different study habits. The results of the study show that the majority of the eleventh-grade underachieving students at Public Senior High School 3 Palembang have good study habits.

The results of the data analysis can also be known more deeply about the aspects of underachieving students' study habits. First, from the aspect of planning and implementing learning schedules, 5 students or $17 \%$ have very good study habits, 21 students or $70 \%$ have good study habits, and 4 students or $13 \%$ have quite good study habits. However, from the total respondents, no students have poor study habits. Second, from the aspect of concentration, 7 students or $23 \%$ have good study habits, 21 students or $70 \%$ have quite good study habits, and 2 students or $7 \%$ have poor study habits. Third, from the aspect of doing assignments, 1 student or $3 \%$ have very good study habits, 18 students or $60 \%$ have good study habits, and 11 students or $37 \%$ have quite good study habits. There are no students who have poor study habits.

Some students with high intelligence have low learning achievements. This is influenced by various factors such as study habits. This study explains that the study habits of underachieving students fall into the good category. A good study habit is when students are able to plan and carry out learning schedules well, have good concentrations, and do their assignments well and timely.

Although the results of the analysis indicate a good category, in the aspect of concentration, 21 students are still in the quite good category and 2 students in the poor category. This is because some students find it difficult to focus on the lesson. The concentration on underachieving students is one factor that influences learning achievements.

Underachieving students find it difficult to pay attention to and concentrate in learning. They have difficulty to follow the lessons in class, especially those that require higher concentrations, such as mathematics [13]. One reason for underachieving students is not being able to focus their attention and to concentrate. Students who have difficulty focusing their minds will find it difficult to understand the lessons given by the teacher [14]. Underachieving students have difficulty understanding the material delivered by the teacher. In general, it is difficult for the students to regulate good study habits in increasing concentrations in learning [15].

Poor concentrations of underachieving students at Public Senior High School 3 Palembang are due to many extracurricular activities they join. In addition, the learning methods provided by some teachers, such as lecturing, make students get bored easily and concentrate less on the lesson. They often complain because of the many tasks given at adjacent time. This makes it difficult for the students to concentrate and causes confusion in doing the assignments. To improve the poor concentration and ability to manage learning planning, the guidance and counseling teacher can provide services accordingly [16]. The acquisition of good learning achievements by underachieving students is determined from the cognition, learning motivation, and 
concentration of students in doing study habits that bring them to the process of good learning activities [17].

The existence of guidance and counseling services has an important role so that the BK teacher can help students recognize and accept themselves and their environment dynamically and positively and enable the students to make decisions, direct and realize themselves effectively and productively according to their desired roles in the future. The problem of poor concentrations in underachieving students' needs to be addressed by the guidance and counseling teacher. The provision of services from the guidance and counseling is needed by underachieving students to improve their learning achievements. The role of guidance and counseling teachers is needed in improving underachieving students' learning achievements. Providing services in learning will increase learning achievements.

The priority service to be provided by the guidance and counseling teachers is to organize guidance and counseling services oriented to the efforts to increase concentrations of learning in the form of information services with service materials in the form of exercises to regulate learning concentrations, the way to improve learning focus, and others. In addition, group-guidance services with themes such as good concentration tips and the right way to focus on learning can also be provided. Students who have poor concentrations can also be provided with individual counseling services that can be useful for digging deeper into the causes of poor students' concentration in learning.

The guidance and counseling teacher can facilitate the potentials of underachieving students. The potentials of underachievers need to be increased in order to achieve the developmental tasks well. Achieving good developmental tasks in learning will result in good learning achievements. This can be done by collaborating with various parties such as parents, subject teachers and class teachers [18].

The roles of parents in increasing the concentration of students in learning are to provide good and adequate learning facilities, to supervise their children's learning activities at home, to supervise the use of children's learning time at home, to monitor children's learning difficulties at home such as concentration in learning, and to help children overcome these difficulties. The role of class teachers is to monitor the development of children's learning achievements to the maximum well. Subject teachers need to increase innovations and creativity in learning, such as such as media, techniques, and models, to make the students not get bored and concentrate on learning according to the students' needs. Teachers must be creative and be able to provide the needs of students. They must know the right learning method and can provide small tasks such as asking the students to clean the blackboard to make them feel that their position in the class is needed and cared for.

Although $70 \%$ of underachieving students have good study habits, the concentrations found in the aspects of learning habits are still not good. The concentrations of underachievers in Public Senior High School 3 Palembang need to be improved with various services, such as group guidance with the theme of good concentration tips and the right way to focus on learning. In addition, the teaching methods of the teachers also need to be improved with more modern ones. This can identify increased students' attentions during the learning process. The role of the guidance and counseling teacher in the school is not only in collaborative efforts with stakeholders in the school but in the achievement of the skills possessed to improve students' academic achievements [19].

\section{CONCLUSION}

Underachieving students' learning habits are classified as good even though the aspect of concentration is not as good as other aspects. Underachievers' concentrations need to be improved. A good increase in concentration will increase underachieving students' learning achievements. The concentrations of underachieving students need to be improved by various services, such as group-guidance services with the theme of good concentration tips and the right way to focus on learning. In addition, the teaching methods of the teachers also need to be improved with more modern ones. This can identify increased students' attentions during the learning process. Teachers should provide support and guidance in schools not only in collaborative efforts with stakeholders in the school but also in the achievement of the skills possessed to improve students' academic achievements.

\section{ACKNOWLEDGEMENT}

This study was only conducted at one school in Palembang. The population in this study were also limited to 30 students. Observations and interviews were conducted directly to underachieving students. Further researchers are expected to conduct studies in other schools with more diverse populations. They can also develop or discover factors other than study habits that influence the learning achievements of underachieving students.Support and assistance were also given by various parties in this study. Senior High School 3 Palembang has helped during the process of data collection until data analysis in this study. Parents and lecturers have helped and supported during the study, as well as the researcher's friends who always accompany and encourage without stopping.

\section{REFERENCES}

[1] Undang-Undang Republik Indonesia No. 20 Tahun 2003, Tentang Sistem Pendidikan Nasional. Surabaya: Karina. 2004

[2] D. Sulistiana, "Program Bimbingan bagi Siswa Underachiever di Sekolah Menengah Atas Negeri 11 Bandung," Jurnal, vol 10, July 2015 .

[3] S. Djamarah, Psikologi Belajar. Jakarta: Rineka Capta. 2011

[4] D. Cavilla, "Observation and Analysis of Three Gifted Underachievers in An Underserved, Urban High School Setting," Gifted Education International, vol. 33, pp. 1-14. November 2015.

[5] H. Rahmat, "Pelaksanaan Bimbingan Kelompok Terinternalisasi Nilainilai Kearifan Lokal (Local Wisdom) dalam Meningkatkan Motivasi Belajar Siswa Underachiever," Prosiding Seminar Nasional Konvensi BK ke-XX \& Kongres ABKIN ke-XIII. 2018.

[6] Nurfaizal, "Understanding of Underachiever Students," Jurnal Fokus Konseling, vol . 2, pp. 76-88. January 2016.

[7] N. Sutringsih, "Penyebab Siswa Underachiever dalam Pembelajaran Matematika,” Jurnal Edumath, vol. 3, pp. 148-154. September 2017.

[8] S. Lelono, "Masalah Siswa Underachiever dan Peran Guru Bimbingan dan Konseling dalam Penanganannya, vol. 5, pp 77-89. December 2011.

[9] C. Berger, "Bring Out the Brilliance: A Counseling Intervention for Underachieving Student," Professional School Counseling, vol 17, pp. 86-96. February 2018 
[10] J. Ritchotte, L. Rubenstein, and F. Murry, "Reversing the Underachievement of Gifted Middle School Students," Gifted Child Today Journal, vol. 38, pp. 103-113. February 2016.

[11] Sumarto, Bimbingan dan Konseling. Jambi: Pustaka Ma'arif Press. 2018.

[12] D. Pratama, "Layanan Bimbingan dan Konseling dalam Mengatasi Siswa Underachiever," Counsellia Jurnal Bimbingan dan Konseling, vol. 7, pp. 1-10. May 2017.

[13] R. S. Dewi, R.S and Mery, "Identifikasi Anak Underachiever," Jurnal Pendidikan: Early Childhood, vol. 1, pp. 1-9. November 2017.

[14] S. Putra, Panduan Pendidikan Berbasis Bakat Siswa. Yogyakarta: Diva Press. 2013.

[15] Linda, "Intervensi terhadap Siswi Underachieving Gifted di Sekolah Internasional "X" Bandung," PSIBERNETIKA, vol. 7, pp. 1-12. October 2014.
[16] S. Arfalah, "Studi Kasus Siswa Underachiever di SMP Negeri 1 Kotabumi Lampung Utara," ALIBKIN (Jurnal Bimbingan dan Konseling, vol. 1, pp. 1-15. 2014.

[17] Syahniar, "Correlation between Self Regulated and Learning Achievement of Underachiever Students," Prociding Education, Social Sciences and Technology, pp. 95-99. February 2018.

[18] R. Rahmawati, Bimbingan dan Konseling untuk Anak Underachiever. Yogyakarta: UNY. 2013

[19] A. S. Bos, F. Herpich, and Guarese, "Educational Technology and Its Contributions in Students' Focus and Attention Regarding Augmented Reality Environment and the Use of Sensors," Journal of Educational Computing Research, vol. 57, pp. 1-17. June 2019 